\title{
Elastic flexure and distributed deformation along Australia's North West Shelf: Neogene tectonics of the Bonaparte and Browse basins
}

\author{
MYRA KEEP ${ }^{1} \&$ MATHEW HARROWFIELD ${ }^{1,2}$ \\ ${ }^{1}$ School of Earth and Geographical Sciences, The University of Western Australia, M004, \\ 35 Stirling Highway, Nedlands, 6009, WA (e-mail: myra.keep@uwa.edu.au) \\ ${ }^{2}$ Current address: Woodside Energy, 240 St George's Terrace, Perth, 6000
}

\begin{abstract}
Neogene collision between Australia and the Banda Arc modified the adjacent Bonaparte and Browse basins of the North West Shelf of Australia. Modification comprised both continuous long-wavelength amplification of Permo-Carboniferous basement topography and flexure and normal faulting of Triassic-Recent sedimentary cover. Deformation was continuous across the Browse and Bonaparte basins, despite the basins beings separated by a rupturebarrier style accommodation zone, the Browse-Bonaparte Transition. The degree of basement control and mechanisms of fault linkage vary significantly across this transition, and reflect differences in the structural relief, amplitude and depth of rifted basement either side of the transition. Neogene collision amplified the architectural divide. Amplification of basement topography over wavelengths of several hundred kilometres was associated with negligible horizontal length change. The transcurrent component of Neogene deformation was partitioned outboard of any continuous flexural amplification.
\end{abstract}

Australia's North West Shelf formed originally as part of an intra-continental rift that commenced during the early stages of Gondwana breakup in the Devonian, and defined several thousand kilometres of the future Australian margin (Yeates et al. 1987). Additional rift events in the Devonian to Permian, Late Carboniferous and Late Triassic to Jurassic created the regional basement architecture and controlled the distribution of source and reservoir horizons of the local hydrocarbon province (e.g. Australian Geological Survey Organisation (AGSO) North West Shelf Study Group 1994; Etheridge \& O'Brien 1994). During the JurassicCretaceous, the punctuated separation of the West Burma blocks resulted in dramatic changes in palaeogeography along the northern and southern parts of the future North West Shelf, resulting in the passive margin that would become the North West Shelf (Etheridge \& O'Brien 1994; Longley et al. 2002). Diachronous collision between Australian continental crust and the Banda Arc from the early Miocene reactivated and modified the Devonian-Cretaceous architecture of the North West Shelf (Fig. 1) (e.g. Baillie \& Jacobsen 1995; Keep et al. 2002).

Despite the currently convergent plate-margin setting, Neogene deformation on the North West Shelf is dominated by normal faults and depocentres rather than by shortening structures (Fig. 2) (Woods 1988; Shuster et al. 1998). Three mechanisms have been proposed to explain this paradox:
(1) localized extension in pockets of the North West Shelf (e.g. Woods 1988); (2) flexural tension of Australia's partially subducted leading edge (O'Brien et al. 1999); and (3) penetrative strike-slip modification of the Timor Sea region (Shuster et al. 1998). Although such models provide a plausible explanation of some depocentre shapes, they are inconsistent with the style and distribution of Neogene deformation.

The adjacent Browse and Bonaparte basins (Fig. 1), thought to represent upper- and lower-plate Lister-style rift compartments (Lister et al. 1991) respectively of the North West Shelf (O'Brien et al. 1999), are separated by a lineament known as the Browse-Bonaparte Transition (Fig. 1) (O'Brien et al. 1993, 1999; Etheridge \& O'Brien 1994; Struckmeyer et al. 1998). The Bonaparte Basin, with its broad outer margin plateau and a narrow margin-parallel graben (Fig. 3a), represents a salient upper-plate rift margin (UPRM), whereas the deeper and more extensive Browse Basin (Fig. 3b) is interpreted as a lower-plate rift margin (LPRM) embayment (O'Brien et al. 1993, 1999). Despite this asymmetry, basement faults trend consistently NE-SW on both sides of the BrowseBonaparte Transition (Fig. 2) (Pattillo \& Nicholls 1990; Struckmeyer et al. 1998; de Ruig et al. 2000).

The NW-SE trending Browse-Bonaparte Transition coincides with deep linear geophysical anomalies (Elliott 1994) and with present-day bathymetry, including dramatic bathymetric 


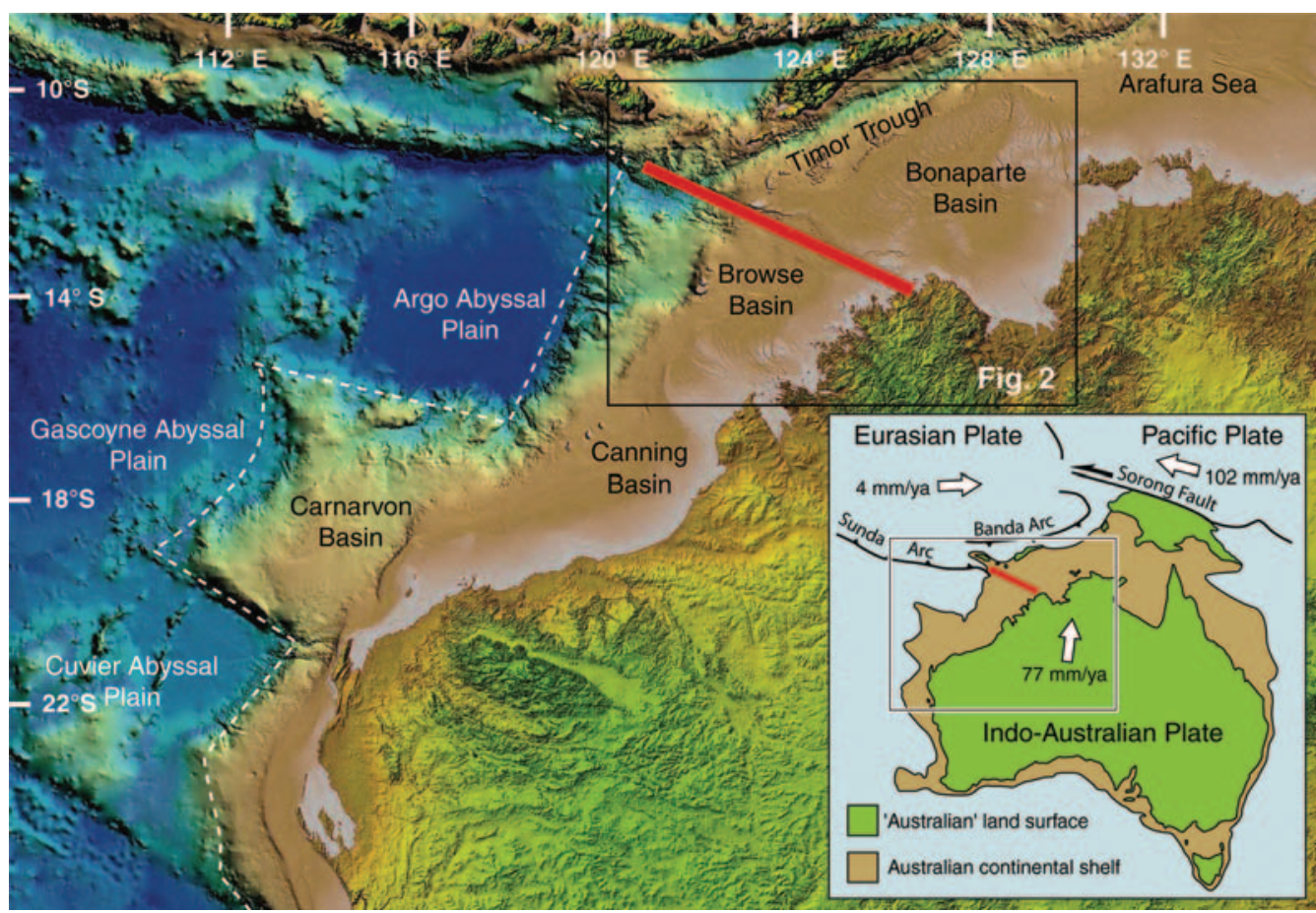

Color

Fig. 1. Bathymetry (AGSO) and tectonic setting of NW Australia. Basement compartmentalization corresponds to basin subdivisions and rectilinear steps in the modern continent/ocean boundary (dashed). Position and geophysical expression of the Browse-Bonaparte Transition is indicated (red). Ongoing collision between Australia and the Eurasia/Pacific Arc system (inset) occurred from the Miocene onward.

changes across the lineament (O'Brien et al. 1993, 1999; AGSO 1994). This transition is interpreted as the accommodation zone across which polarity of the Permo-Carboniferous rift reversed (O'Brien et al. 1993; Etheridge \& O'Brien 1994). Whether the structure represents a fault-bound 'transfer' style (e.g. Hayward \& Ebinger 1996) or continuous 'rupture-barrier' style (e.g. Faulds \& Geissman 1992) feature of basement architecture remains unclear. The Browse-Bonaparte division reflects compartmentalization of the wider North West Shelf over length scales of $600-700 \mathrm{~km}$, corresponding to the Carnarvon, Browse/Canning and Bonaparte basins (Fig. 1) (O'Brien et al. 1993, 1999).

We present a synthesis of Neogene tectonism in the Browse and Bonaparte basins and attempt to reconcile the growth of major Neogene depocentres with brittle normal faults in a convergent plate boundary setting. In particular, we relate apparent Neogene subsidence to modification of the basement architecture. Structural and stratigraphic data from the Bonaparte and Browse basins are presented and we examine differences in the style and intensity of the Neogene deformation across the Browse-Bonaparte Transition. In addition we describe the nature of the Browse-Bonaparte Transition and relate long-lived compartmentalization of the North West Shelf to weak episodic tectonic modification.

\section{Geological framework and tectonostratigraphy}

A 2D two-way-time (TWT) seismic grid spanning the Browse and Bonaparte basins was mapped and tied using around 40 wells for which Tertiary Q1 picks were determined (Fig. 4). This grid, comprising more than 4000 open-file lines with an average line spacing of around $5-10 \mathrm{~km}$, was used to construct structural cross-sections and to correlate fault projections across the area. Stratigraphic mapping of the Bonaparte Basin (Fig. 5) shows detailed isochores at selected intervals from the Permian to the seafloor. Similar maps for the Browse Basin (Fig. 6) appear courtesy of Woodside Energy Ltd, after Longley et al. (2002).

Although basement on this part of the North West Shelf, especially coring the underlying 


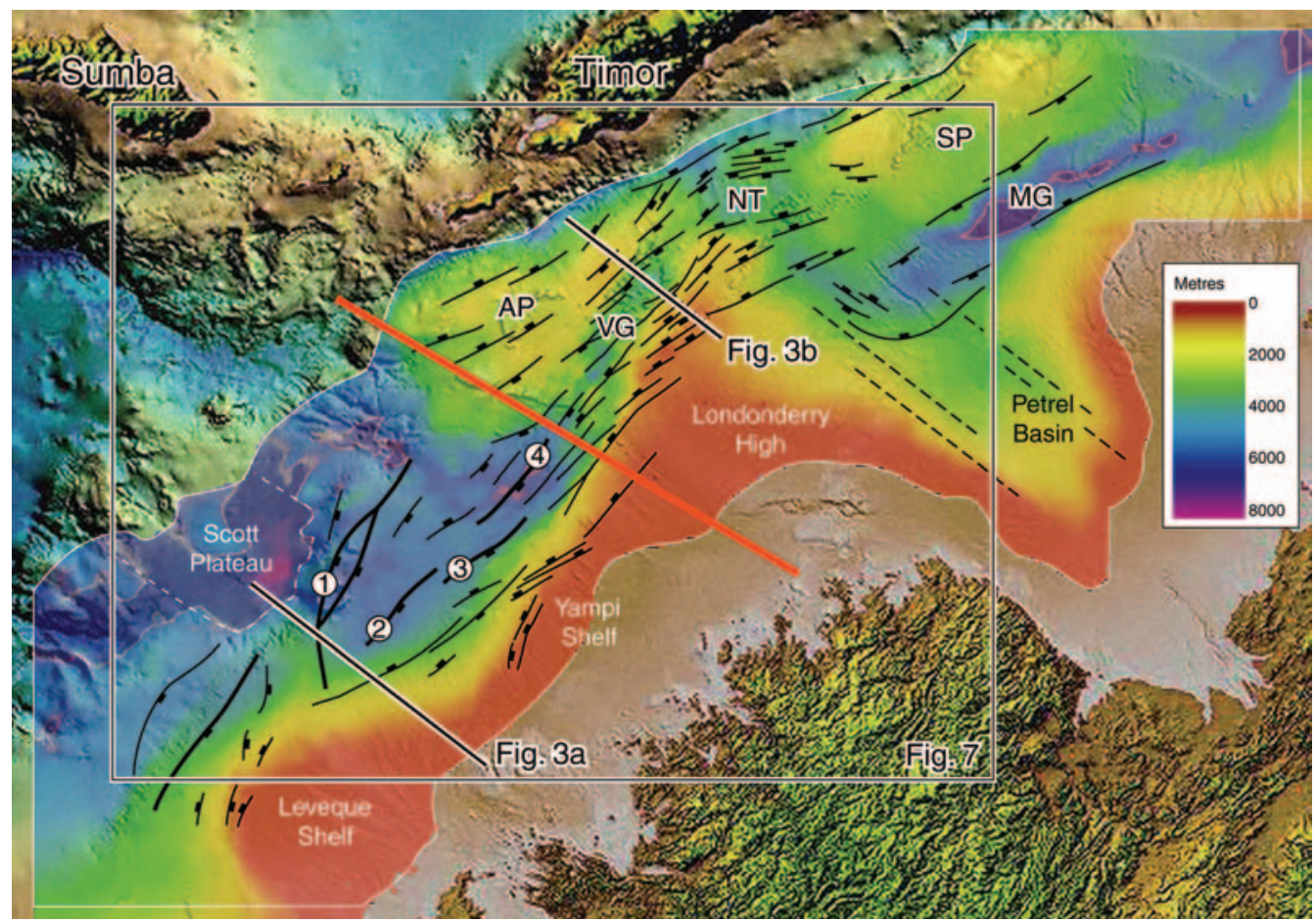

Fig. 2. Basement fault trends across the Browse and Bonaparte basins after Pattillo \& Nicholls (1990), Struckmeyer et al. (1998) and de Ruig et al. (2000), superimposed upon the Oxfordian isochore (after Longley et al. 2002). The Bonaparte upper-plate is marked by the outer-margin highs of the Ashmore (AP) and Sahul (SP) platforms, separated from the Londonderry High (LH) by the Vulcan (VG) and Malita (MG) grabens and Nancar Trough (NT). The Browse-Bonaparte Transition is shown by the red line. Major basement faults of the Browse Basins (bold) after Struckmeyer et al. (1998): (1) Scott Reef Fault Trend, (2) Caswell Fault, (3) Brewster Fault and (4) Bassett Fault. The earlier structural grain of the Petrel Basin (dashed) reflects failed Devonian-Carboniferous rifting (O’Brien et al. 1993).

structural highs, is thought to be Precambrian in age, the oldest and deepest horizon that can be correlated across the Bonaparte and Browse basins is the regional Oxfordian (JO) unconformity (Fig. 7a). However, locally in the Bonaparte Basin the top Permian surface can also be identified (Fig. 5a). Within this local top Permian surface the basement architecture of the Bonaparte Basin, including major troughs and highs, can be identified (Fig. 5). Above this surface the top PermianAptian isochore (Fig. 5b) reflects both PermoTriassic infill and more localized syntectonic Jurassic-Cretaceous sedimentation.

The Oxfordian (JO) horizon map clearly illustrates changes in Mesozoic structural relief between the Browse and Bonaparte basins. In the southern Bonaparte Basin, the amount of Oxfordian structural relief (Fig. 7a) is virtually identical to that of the top Permian (syn-rift) surface (Fig. 5a). By comparison, Oxfordian (JO) structural relief in the Browse Basin was probably of lesser amplitude than the underlying syn-rift architecture (Fig. 7). In both basins, the amplitude of Oxfordian structural relief exceeds that of all younger horizons.

Limited Oxfordian-Valanginian (JO-KV) deposition was confined to the Vulcan Graben and a depocentre in the central Browse Basin (Fig. 7b), whilst the Valanginian-Aptian (KVKA) isopach only records a depocentre in the Browse Basin (Fig. 7c). This limited deposition in both the Browse and Bonaparte basins at this time reflects a combination of protracted post-Oxfordian underfill of the Browse Basin (Longley et al. 2002) and late Jurassic uplift and Aptian erosion of the Bonaparte Basin (Duddy et al. 2004). Both are consistent with structural relief between the two basins during the early Cretaceous and greater accommodation space within the Browse Basin at that time.

Infill of Oxfordian structural relief within the Browse Basin was completed during the late Cretaceous (Longley et al. 2002). Peak eustatic 


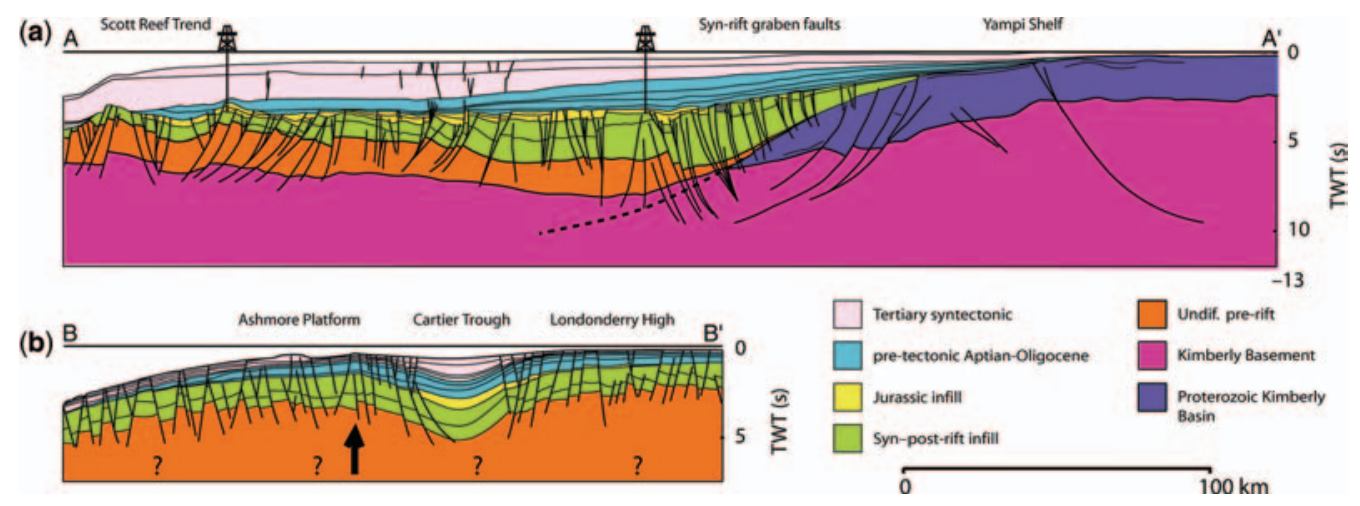

Fig. 3. Published cross-sections across the (a) Browse Basin (AGSO, 1994) and (b) Bonaparte Basin (Harrowfield et al. 2003). Black arrow marks approximate axis of saddle topography. See Figure 2 for section locations.

sea levels during the Turonian (Blevin et al. 1998) culminated in onlap of the Scott Reef Trend (Fig. 3a) and infill of relief across the BrowseBonaparte Transition (Fig. 7d), permitting convergence of Maastrichtian fan systems across the two basins (Blevin et al. 1998). The core of the Q1 Aptian-base Tertiary (KA-T) depocentre lay adjacent to the mouth of the Vulcan Graben and well inboard of the Scott Reef Trend (Fig. 7e). The Bonaparte Basin, having been eroded to a low-relief shelf during the Aptian (KA), was subsequently covered by a relatively uniform Aptian-Miocene blanket that has no obvious sensitivity to older topography (Fig. 5d) (Harrowfield et al. 2003). Apparent thinning of this blanket across the
Ashmore Platform (Fig. 7e) reflects subsequent Neogene erosion (Hillis 1992). The Oligo-Miocene unconformity (Fig. 5e) preserves a similar topography to that of the Aptian unconformity. This topography must therefore post-date deposition of the Aptian-Oligo-Miocene succession.

In the Bonaparte Basin the Neogene-Recent isochore (Fig. 5f) illustrates thick deposits in the Cartier and Nancar troughs and Malita Graben, mimicking those seen in the top Permian surface (Fig. 5a). Thickness variations in this Neogene to Recent isochore reflect infill of the underlying base Tertiary (TO) unconformity (Fig. 5e) and cor- Q1 responds to Neogene fault trends across the North West Shelf (Fig. 2).

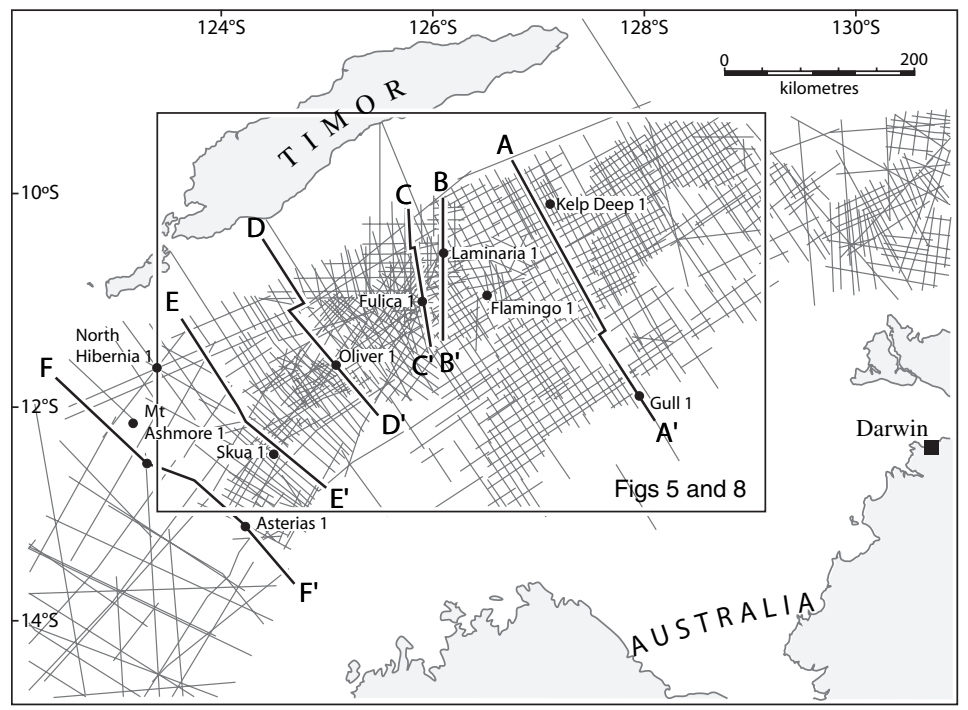

Fig. 4. Seismic base map of the Timor Sea region illustrating open-file seismic lines and selected commercial wells used in the course of this study. The locations of strike-normal (cross-sections (A-F) and the location of Figures 5 and 8 are also shown. 

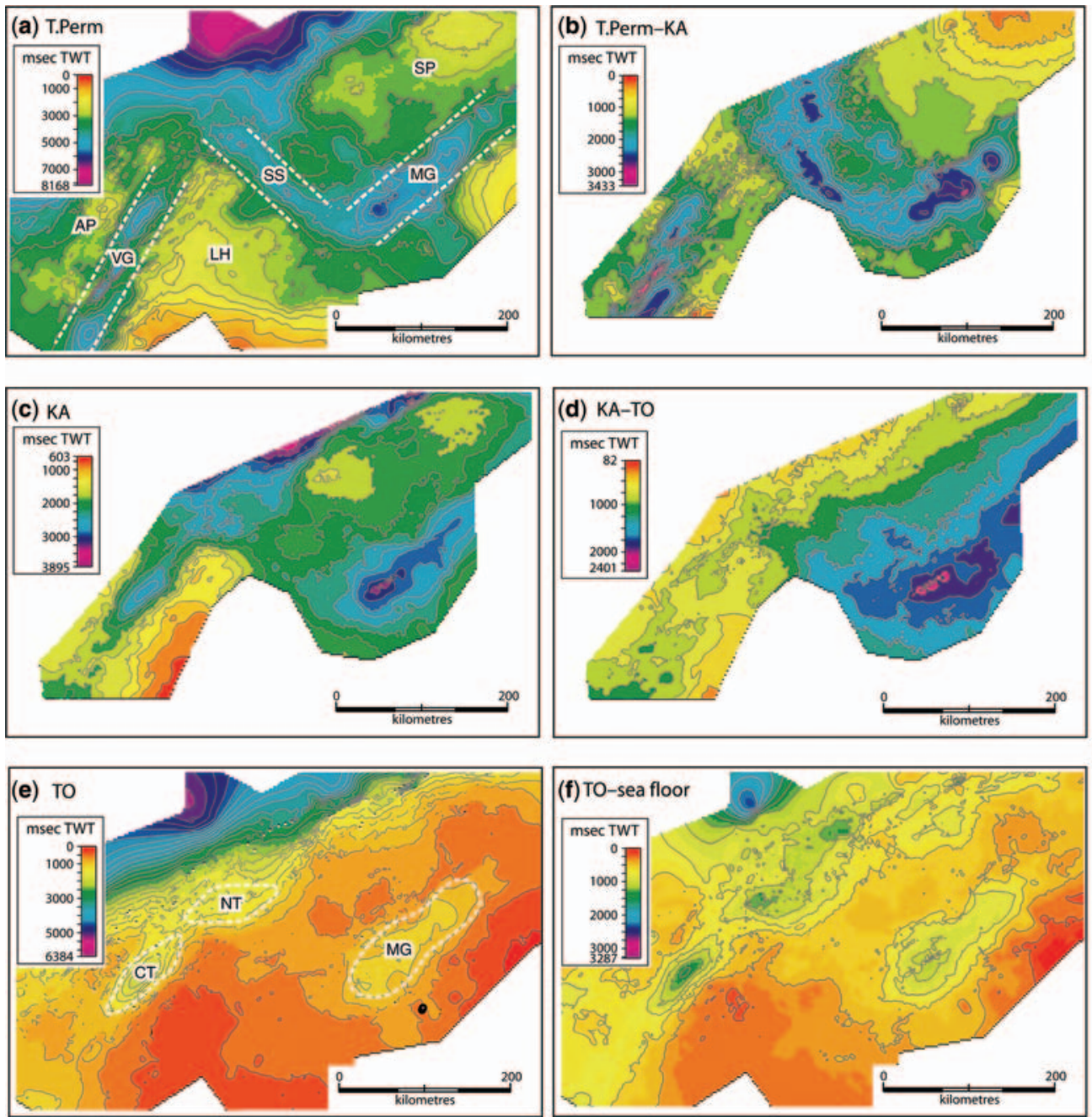

Fig. 5. Tectonostratigraphy of the Timor Sea region, indicating major physiographic features (see Fig. 4 for field of view): (a) Top-Permian (T.Perm) time surface map with two-way travel time (TWT) contoured at 400 ms intervals; (b) Top-Permian-Aptian (KA) isochore, contoured at $200 \mathrm{~ms}$ intervals; (c) time-surface map of the KA unconformity, contoured at $200 \mathrm{~ms}$ intervals; (d) Aptian-Oligo-Miocene (TO) isochore contoured at $200 \mathrm{~ms}$ intervals; (e) time-surface map of the TO unconformity contoured at $200 \mathrm{~ms}$ intervals; (f) TO-sea floor isochore contoured at 200 ms intervals. VG, Vulcan Graben; SS, Sahul Syncline; MG, Malita Graben; AP, Ashmore Platform; LH, Londonderry High; SP, Sahul Platform; CT, Cartier Trough; NT, Nancar Trough.

The Neogene sedimentation history of the Bonaparte Basin therefore mimics that of the underlying Permian surface, and all major NeogeneRecent depocentres (Vulcan Graben, Malita Graben, Sahul Syncline) directly overlie older Palaeozoic-Mesozoic troughs (compare Fig. 5a, b \& f). This virtually identical topographical growth in the post-Permian and the Neogene occurs despite the change in tectonic regime from extensional to contractional in the intervening $120 \mathrm{Ma}$ of continuous passive margin sedimentation. The distribution of Neogene sediments appears to have been structurally controlled and associated with a fault-propagated topography (Figs $2 \& 5 f$ ).

In the Browse Basin the longevity of the depocentres is more subtle than in the Bonaparte Basin. Depocentres in the base Tertiary-waterbottom isopach (Fig. 7f), differ significantly from Q1 those in the upper Cretaceous interval (Fig. $7 \mathrm{~d} \&$ e) in that the Tertiary depocentre did not form alongstrike from the palaeo-Vulcan Graben (compare Fig. 7e \& f), even though that feature experienced
Color

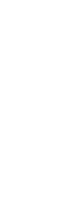


(a)

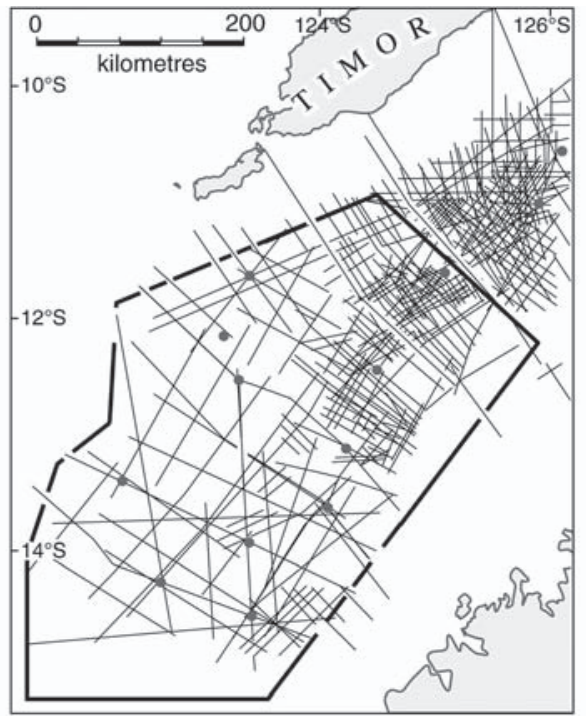

(c) TO-seafloor isochore

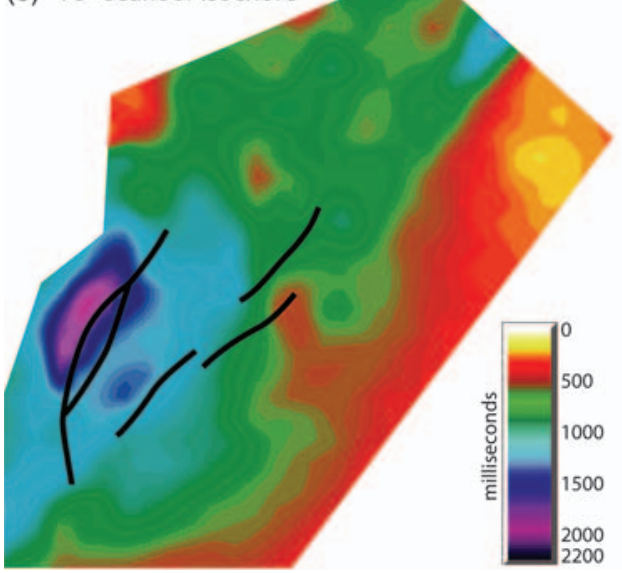

(b) KA-TO isochore

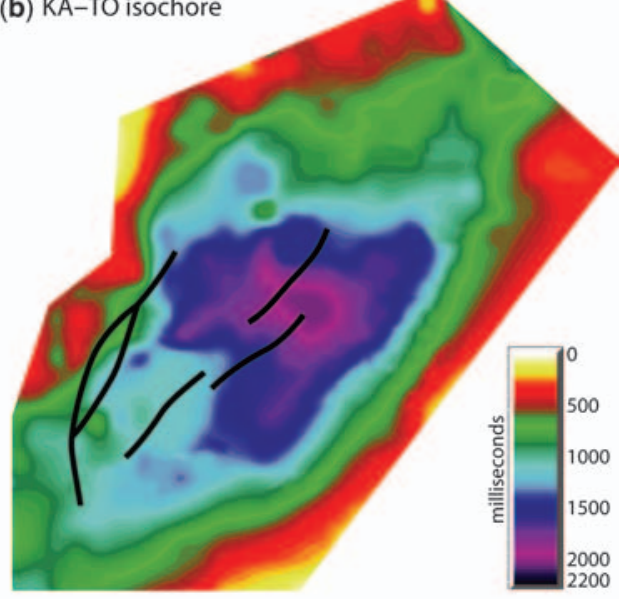

(d) B.Pli.-seafloor isochore

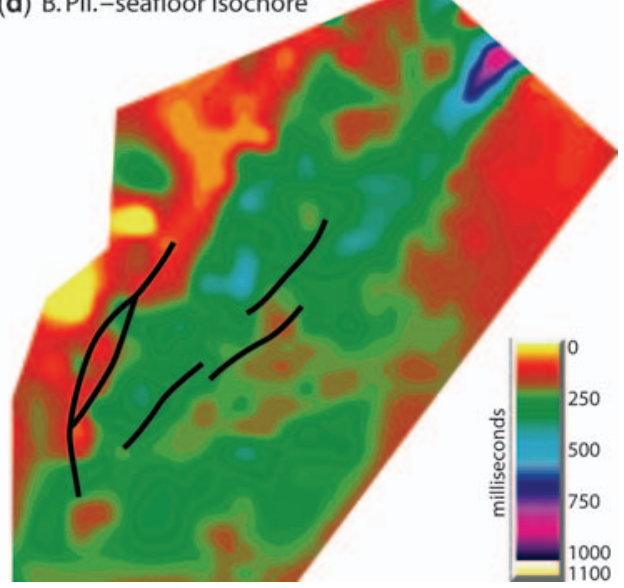

Color

Fig. 6. Detail of the late Cretaceous and Tertiary (Albian-seafloor) history of the Browse Basin, mapped from

(a) local 2D seismic grid: (b) pre-tectonic Aptian (KA)-Oligocene (TO) isochore; (c) early syn-tectonic

Oligocene (TO)-base Pliocene isochore; and (d) base-Pliocene-water bottom isochore. Major basement faults as per Figure 2.

subsidence during the Neogene (Chen et al. 2002; Harrowfield et al. 2003). Instead, deposition migrated westward and southward (Fig. 6a \& b), with the greatest thicknesses accumulating above the deepest regions of Oxfordian structural relief (compare Fig. 7a \& f). The Pliocene-Recent component of this depostional wedge is bound by a margin-parallel trough with linear discontinuities that coincide with syn-rift basement faults (Fig. 6d).

Q1 Tertiary sedimentation in the Browse Basin therefore reflects a combination of depocentre progradation and the influence of structural relief associated with the Scott Reef Trend, Oxfordian depocentre and Browse/Bonaparte Transition. These features were not relics of Jurassic architecture, which had been infilled during the mid-late Cretaceous (Figs $6 \& 7$ ). Neogene rejuventation of these structural elements was spatially and temporally associated with Neogene faulting and syntectonic sedimentation across the Browse and Bonaparte basins.

\section{Neogene deformation}

In the Bonaparte Basin the top Permian surface (Fig. 5a) displays fault-bound grabens associated 

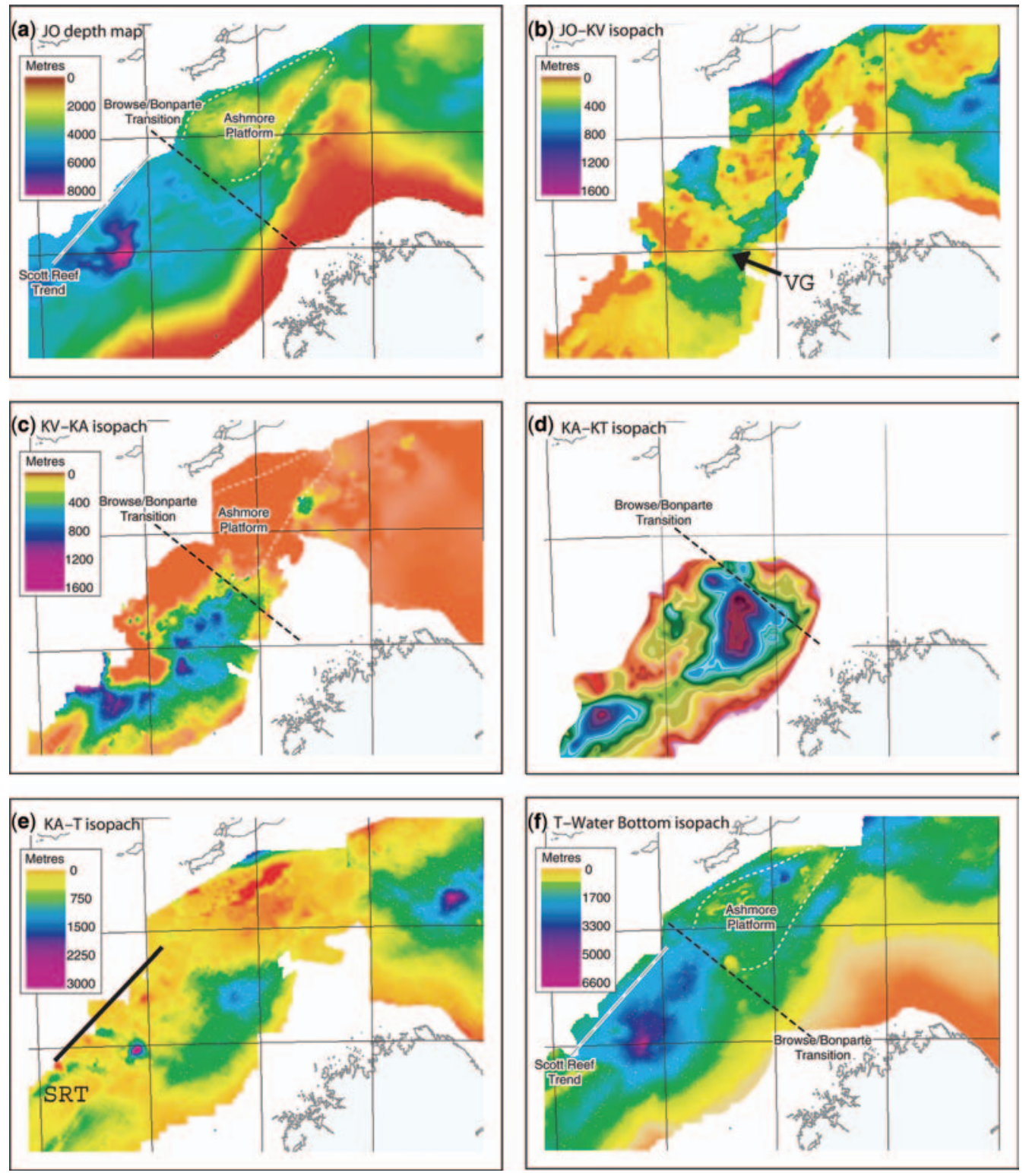

\section{Color}

Fig. 7. Major tectonostratigraphic intervals across the Browse and Bonaparte basins after Longley et al. (2002), courtesy of Woodside Energy Ltd. (a) the Oxfordian (JO) unconformity, the oldest and deepest horizon that may be traced continuously across the two basins; (b) the Oxfordian-Valanginian (KV) isopach; VG, Vulcan Graben;

(c) the Valanginian-Aptian (KA) isopach; (d) the Aptian-Turonian (KT) component (Blevin et al. 1998; no scale given) of (e) the Aptian (KA)-base Tertiary (T) isopach; black line shows position of the Scott Reef Trend (SRT); and (f) base Tertiary-water bottom isopach. See Figure 2 for location.

with deep-seated listric detachments (e.g. Australian Geological Survey Organisation (AGSO) North West Shelf Study Group 1994; O’Brien et al. 1999). The Oxfordian surface in contrast (Fig. 7a) reflects Jurassic subsidence and renewed subsidence of pre-existing toughs, with infill of these lows prior to the Aptian (e.g. Longley et al. 2002).

Internally, the Aptian-Oligocene sequence (Fig. 3b) displays continuous sedimentary packages 
that prograde offshore, and generally reflects an advancing sedimentary wedge. This sequence has been distorted about a younger saddle-like topography (Fig. 3b).

Neogene-Recent sedimentation reflects infill of the fault-bound saddle-like topography (since the onset of plate collision), with portions of the sequence thinning across developing highs or thickening above deepening troughs (Fig. 8). As the margin is currently shortening, resulting in an overall decrease of accommodation space, the thinning and thickening of sediments reflect only apparent uplift and apparent subsidence. The coincidence of thinned, fault-bound segments in successive packages (Fig. 8) indicates that thinning was related to both differential uplift and topographic drape. In all cases, synsedimentary thinning and apparent uplift appear to have begun in the late
Oligocene or early Miocene and to have continued well into the Plio-Pleistocene.

Structural highs bounded by brittle normal faults in the Bonaparte Basin have previously been attributed to a horst-like architecture (Woods 1988; de Ruig et al. 2000; Chen et al. 2002). However, these highs (Fig. 8) are not associated with discrete structural thickening. Between major faults the Tertiary horizons commonly exhibit convex-up geometries (Fig. 8), that are harmonic throughout Q1 the stratigraphy and are thought to reflect minor distributed shortening within fault-bound segments. Neogene depocentre margins are marked by prominent normal faults (Fig. 8), many of which are coincident with down-to-basement faults at Mesozoic levels. Apparent subsidence and fault growth appear to have peaked during the late Miocene or Pliocene.
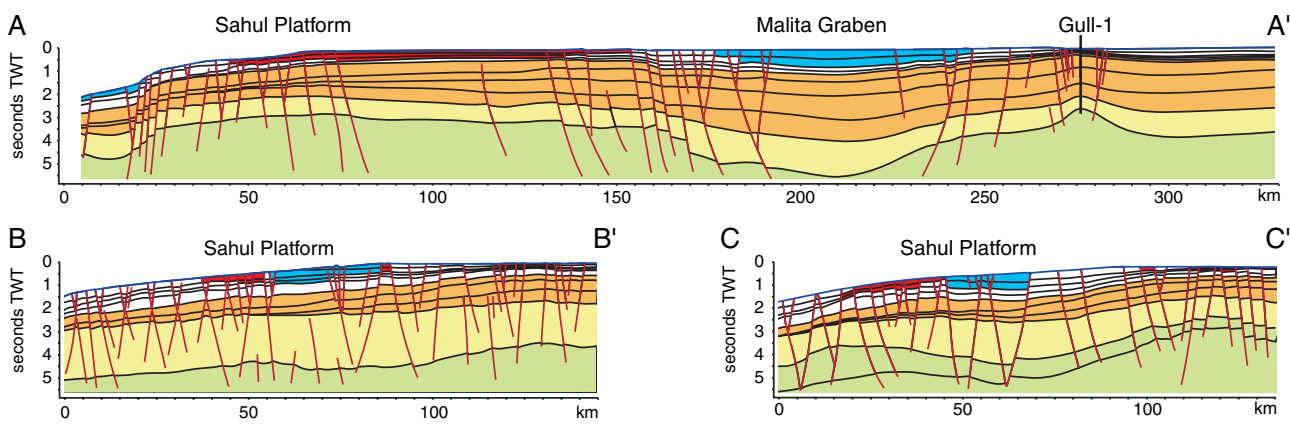

$B^{\prime} \quad \mathrm{C}$

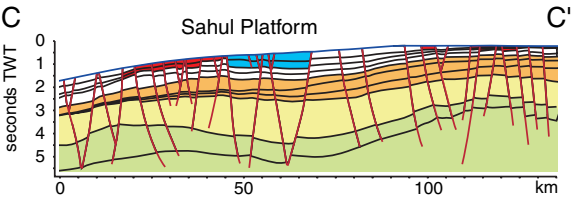

\section{pre-T Permian}

undiff. Permian-Callovian/Oxfordian

Callovian/Oxfordian-Oligo-Miocene

Neogene

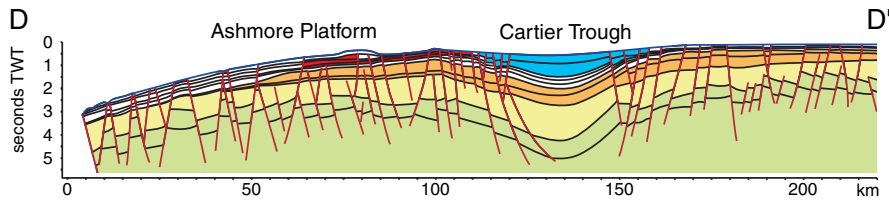

apparent Neogene uplift

apparent Neogene subsidence

Major fault

x3 vertical exaggeration
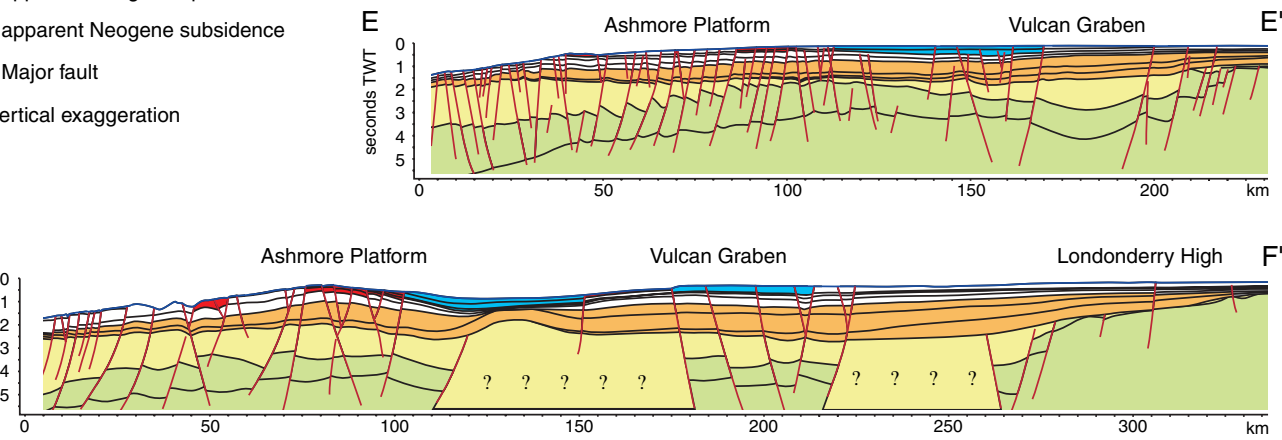

Fig. 8. Interpretation of apparent Neogene topography, based on variations of sedimentary thickness $(\times 3$ vertical exaggeration). Deepening depressions in the unconformity at the top of the Oligo-Miocene (orange) were bound outboard by diffuse horst-like structural highs. The Cartier Trough, $\left(\mathrm{C}-\mathrm{C}^{\prime}\right)$ is also bound inboard by zones of lesser uplift; an apparently similar phenomena on the inboard margin of the Malita Graben $\left(\mathrm{A}-\mathrm{A}^{\prime}\right)$ reflects a salt diapir beneath the Gull-1 well. Locations of cross-sections given on Figure 4. 
The proliferation of seaward-dipping and landward-dipping normal faults, commonly coincident with the older syn-rift architecture at depth (Woods 1988; Nelson 1993; O'Brien et al. 1993) makes characterizing Neogene deformation kinematics difficult. However, in the Bonaparte Basin, clear relationships between normal faulting, distortion of pre-collisional cover and the distribution of syn-tectonic (collisional) sediment assist the identification of long wavelength deformation kinematics and four structural domains (Fig. 9):

(I) a zone of dominantly seaward-verging normal faults that may be traced around the inboard margins of the Vulcan Graben;

(II) a zone of dominantly landward-verging normal faults, bounding the outboard margin of the Vulcan Graben;

(III) a zone of dominantly seaward-verging fault kinematics that envelope the outboard flank of the Ashmore Platform; and

(IV) weak, dominantly outboard-dipping normal faults in the vicinity of the Scott Reef Trend, along strike from the Lynher/Lombardina trend of the outer Browse Basin (Fig. 10).
In the central Bonaparte Basin these Neogene faults commonly preserve modern seafloor offsets (Fig. 9A-A'). Domains I and II (Figs $9 \& 10$ ) illustrate down-warping of Cretaceous horizons beneath the Neogene fill of the Vulcan Graben; in domains II and III faults shed pre-collisional cover from the rising and eroding Ashmore Platform (Figs 9 \& 10).

Reduced structural relief in the Browse Basin makes extrapolation of these domains from the Bonaparte Basin into the Browse Basin difficult, and is exacerbated by the low intensity of brittle deformation and the thinness of the Neogene fill in the Browse Basin. However, coarse extrapolation of the structural domains may be achieved via correlation of Neogene subsidence/uplift, Pliocene sedimentary growth and, locally, by rare kinematic consistency of normal faults (Fig. 11).

The structural grain of Neogene faults across the Bonaparte and Browse basins changes from NESW-trending across the Ashmore Platform and Vulcan Graben, the Browse-Bonaparte Transition and the northern reaches of the Browse Basin to east-west trending in the centre of the Browse Basin (Fig. 10). There is no discrete structural

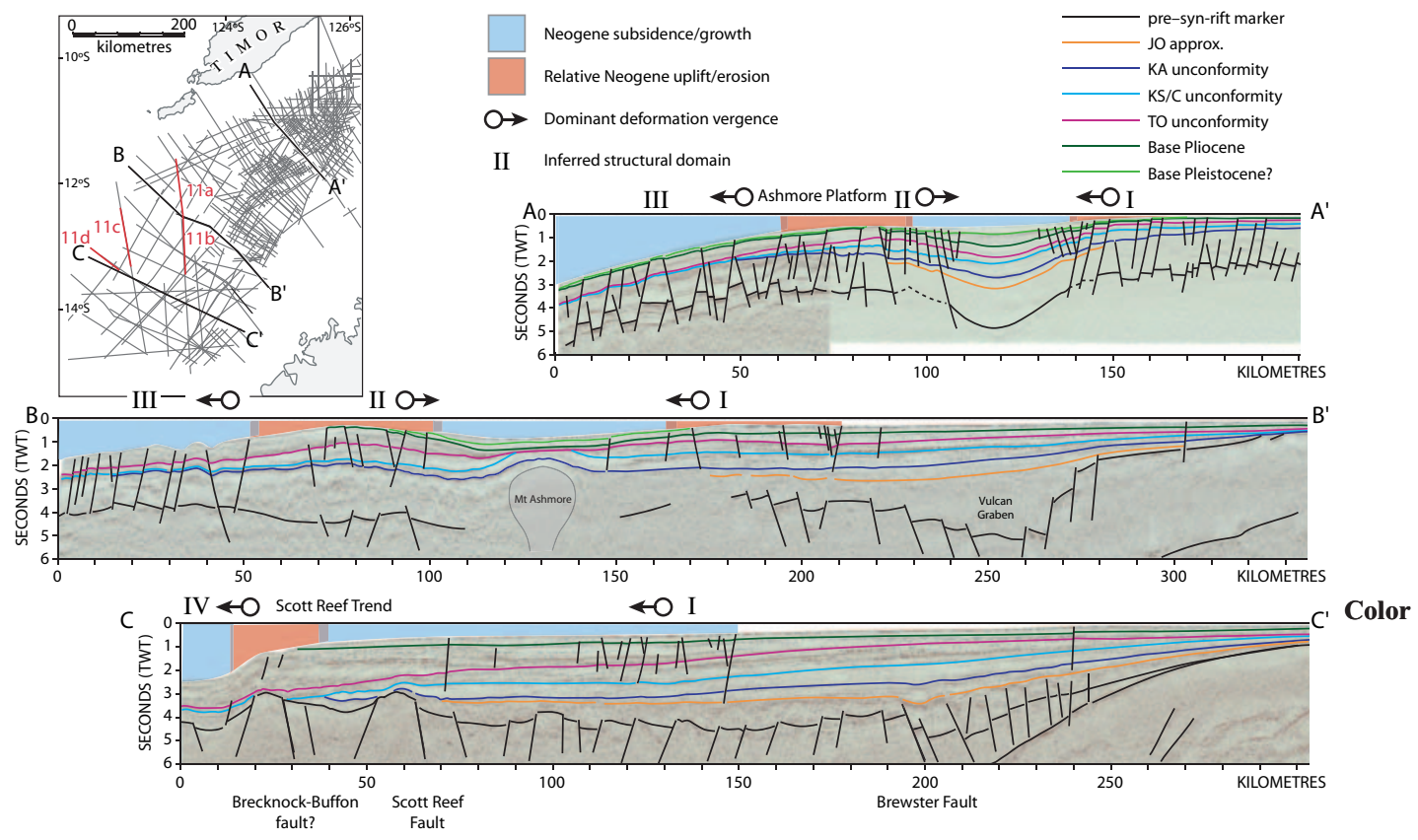

Fig. 9. Neogene deformation vergence, extrapolated southward from the Bonaparte Basin $\left(A-A^{\prime}\right)$ on the basis of syn-tectonic Mio-Pliocene sedimentation. Dissection of the Ashmore Platform is continuous with buckling of Cretaceous-Oligocene horizons and sedimentary thinning west of Mt Ashmore. These zones of uplift bound Plio/Pleistocene depocentres within the Vulcan Graben and above Mt Ashmore $\left(\mathrm{B}-\mathrm{B}^{\prime}\right)$. The central Browse Basin is dominated by sparse, NW-verging faults and deformation associated with the Scott Reef Trend $\left(\mathrm{C}-\mathrm{C}^{\prime}\right)$. Approximate vertical exaggeration $\times 12$. 


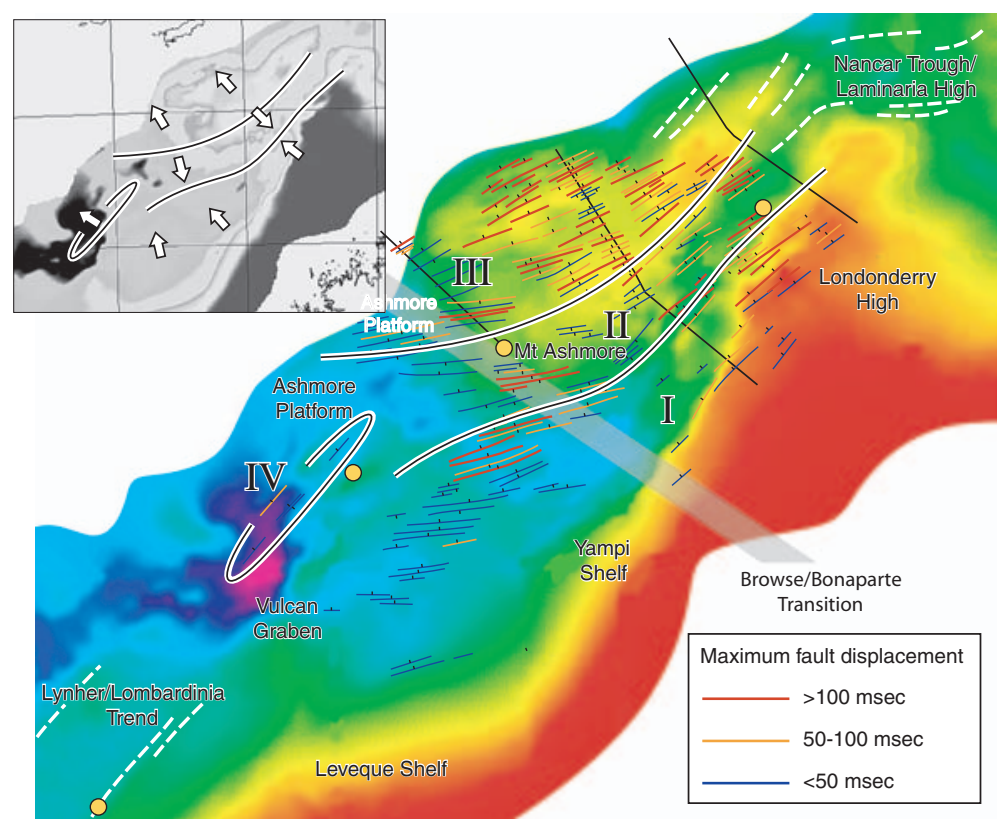

Color

Fig. 10. Interpreted Neogene fault trends across the Browse and Bonaparte basins, coloured according to maximum post-Oxfordian TWT offset. Inferred structural zonation and generalized fault vergence directions (inset) are extrapolated southward from the Bonaparte Basin (Fig. 11).

expression of the NW-trending Browse-Bonaparte Transition. We make several observations of Neogene deformation in the Browse Basin:

- Neogene faults are predominantly confined to the centre of the basin (Fig. 10);

- individual fault segments have negligible expression in Tertiary surface/isochore maps (Figs 6 \& 7f) and rarely have maximum displacements greater than $100 \mathrm{~ms}$;

- faults do not penetrate the Yampi Shelf or vicinity of Mt Ashmore; and

- pervasive faulting north and west of $\mathrm{Mt}$ Ashmore is continuous with deformation of the Ashmore Platform (Fig. 10).

Neogene modification of the Browse Basin is also manifested as continuous deformation of precollisional strata. The present-day bathymetric profile across the Browse-Bonaparte Transition coincides with continuous down-warping of Cretaceous-Miocene horizons (and ponding of Pleistocene-Recent sediments above the Mt Ashmore intrusion) (Fig. 9B-B' ).

Continuous Neogene deformation is also observed along the outer margin of the Browse Basin, with Mio-Pliocene prograde expansion and concave-up warping on the outboard side of the Scott Reef Trend (Fig. 11c), and increased relief between the Scott Reef Trend/Browse Basin and
Scott Plateau (O'Brien et al. 1993). Likewise, tapering of the Pliocene wedge behind this topographic front (Fig. 9b), corresponding to linear expressions in the Tertiary isopach and Pliocene isochore Q1 (Figs 6c \& 7f ) suggests uplift or amplification of the Scott Reef Trend. The uplifted outer flank of the Scott Reef Trend and its along-strike equivalents formed a locus for Pliocene canyon development (Fig. 11c \& d).

Throughout the region, and particularly in the Bonaparte Basin, Neogene faults commonly coincide with larger displacements at Mesozoic levels (Fig. 9) (e.g. Woods 1988; de Ruig et al. 2000; Chen et al. 2002). This inheritance of extensional architecture, seemingly at odds with the contractional setting of Neogene deformation, has been variously explained in terms of tensional (Woods 1988), strike-slip (Keep et al. 2000) and flexural deformation (Harrowfield et al. 2003). Although cover and basement faults are typically continuous in 2D seismic cross-section, their displacement profiles are not continuous down-plane (Woods 1988; de Ruig et al. 2000). Typical faults have maximum displacements at late Miocene/Pliocene levels, coincident with peak syn-sedimentary Neogene growth (Fig. 9). This growth declines abruptly below the Base Tertiary unconformity: Q1 however, and displacements penetrate pre-collsion levels and decay down-plane towards typical 

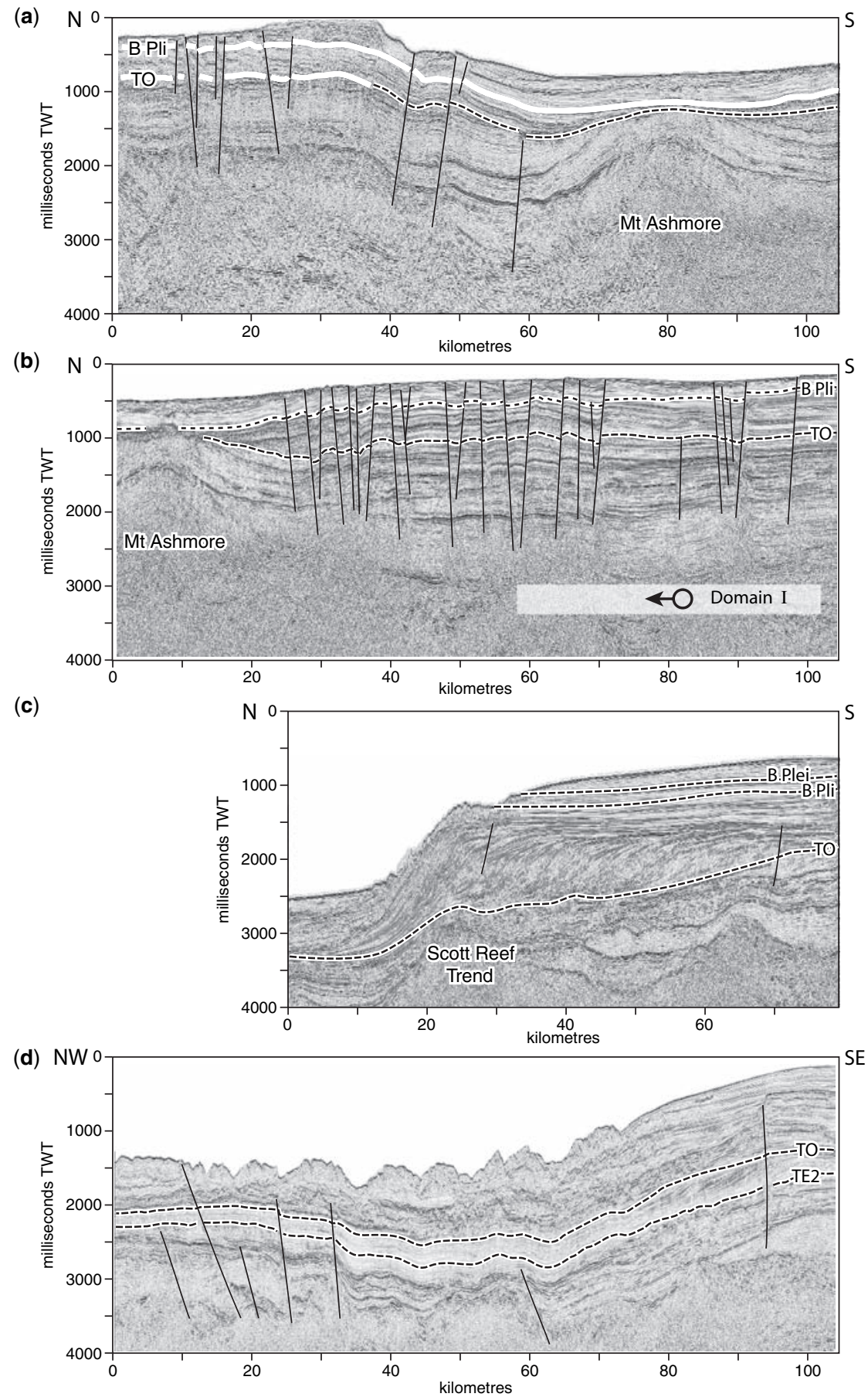

Fig. 11. Continuous Neogene deformation in the Browse Basin (see Fig. 9 for section locations): (a) down-warping of Tertiary strata across the Browse-Bonaparte Transition and buckling of pre-tectonic packages above Mt Ashmore; (b) rotational distortion of package boundaries between adjacent Neogene normal faults, kinematically consistent at right; (c) down-warping of pre-tectonic horizons, and confinement of the Pleistocene wedge across the Scott Reef Trend. Uplift of this trend (c), and its along-strike equivalents (d), induced canyon incision on the outboard flank. Approximate vertical exaggeration $\times 12$. 
minima around the Campanian or Aptian unconformity (de Ruig et al. 2000). Displacement increases abruptly again near the Oxfordian unconformity, culminating in large offsets and growth at syn-rift (Mesozoic) levels (Fig. 9) (Chen et al. 2002). Such profiles are not consistent with temporally continuous displacement at all levels of the pile (Walsh \& Watterson 1987). Rather, these profiles are thought to reflect juxtaposition of Permian, Jurassic and Neogene offsets. Although fissiontrack annealing episodes might indicate basinal brine transport and basement fault reactivation (Duddy et al. 2004), the connectivity of Lower Cretaceous hydrocarbon seals suggests that such reactivation was not necessarily continuous with brittle deformation of the upper sedimentary pile (de Ruig et al. 2000). This uncoupling of basement and cover faulting is thought to have permitted flexure of cover rocks about reactivated basement architecture (Harrowfield et al. 2003).

\section{Discussion}

We believe Neogene modification of the Bonaparte Basin reflects an amplification of syn-rift basement topography. This amplification appears to have decreased inboard over wavelengths of 200$300 \mathrm{~km}$, penetrating to inboard depocentre margins only in the more highly deformed Cartier and Nancar troughs (Fig. 12). We attribute apparent Neogene subsidence in the Timor Sea to forebulge flexure, and suggest that propagation of this flexure was limited to the leading several hundred kilometres of the Australian margin. This limitation probably reflects the rapid lateral decay of elastic potential and increasing lithospheric thickness toward the continent proper.

Deformation of the Bonaparte Basin is thought to have absorbed minor margin-parallel shortening, oblique to the trajectory of the Indo-Australian Plate (Fig. 1). Although this shortening must have been accompanied by a component of left-lateral deformation (e.g. Shuster et al. 1998), our observations suggest that this strike-slip component was partitioned outboard of the major Neogene depocentres, and may have been localized against the outboard margins of the Sahul and Ashmore platforms (Fig. 2) (Nelson 1993; Keep et al. 2002).

The Browse-Bonaparte Transition has no discrete structural expression. Neogene fault trends, although oblique to the transition, are continuous across it (Fig. 10). We identify a correlation between the trend and vergence of Neogene normal faults and the architectural topography of the Oxfordian (JO) unconformity. The rotation of Neogene structural grain across the BrowseBonaparte Transition mimics the curvature of JO

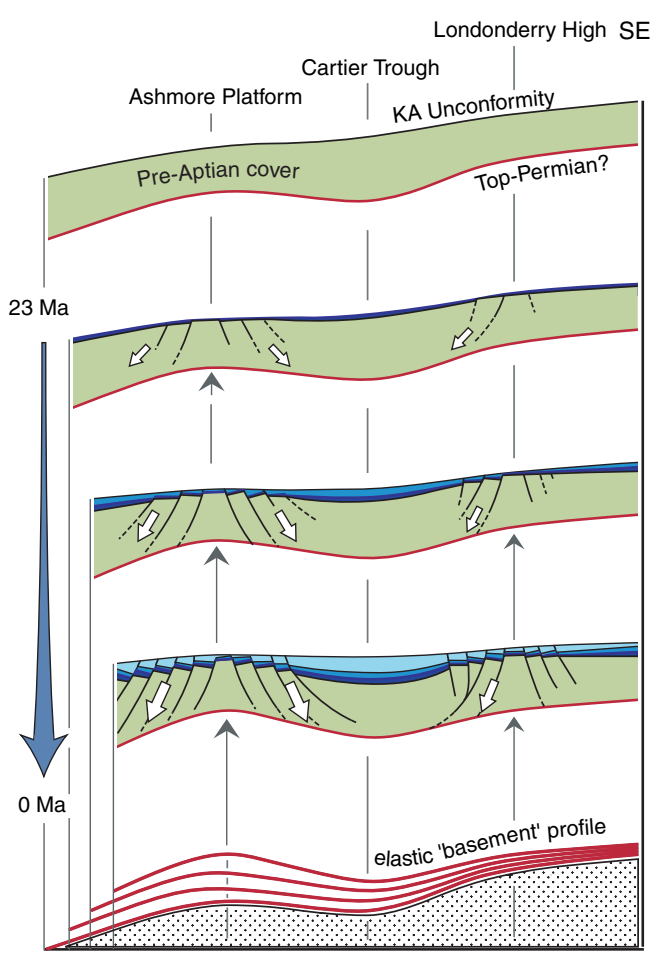

Color

Fig. 12. Conceptual evolution of Neogene architecture. In contrast to these schematic illustrations, Neogene shortening is thought to have been minuscule: approximating a $1.5 \mathrm{~km}$ amplitude parabolic flexure across the $c .100 \mathrm{~km}$ wavelength Ashmore Platform yields an effective shortening of $0.05 \%$.

topographic contours and the arcuate geometry of the Yampi/Leveque Shelf (Fig. 10). This rotation describes an architecture in which normal faults throw broadly perpendicular to JO architectural topography (Fig. 10, inset).

The control on Neogene faulting by basement architecture changes across the Browse-Bonaparte Transition. Neogene deformation of the Bonaparte Basin was tightly controlled by fault-bound basement structural relief (Harrowfield et al. 2003), with flexure and normal faults co-axial with syn-rift architecture (Figs 9A-A', 13). This suggests hard-linkage of parallel cover and basement faults (e.g. Nelson 1993; Shuster et al. 1998). In the Browse Basin, shallow Neogene normal faults and structural domains trend oblique to syn-rift structure, suggesting Neogene faults were probably soft-linked to basement architecture. For example, in the central Browse Basin shallow Neogene faults localize above structural culminations bound by the JO unconformity. We envisage three probable reasons for this relaxation of basement control: first, reduced amplitude and 

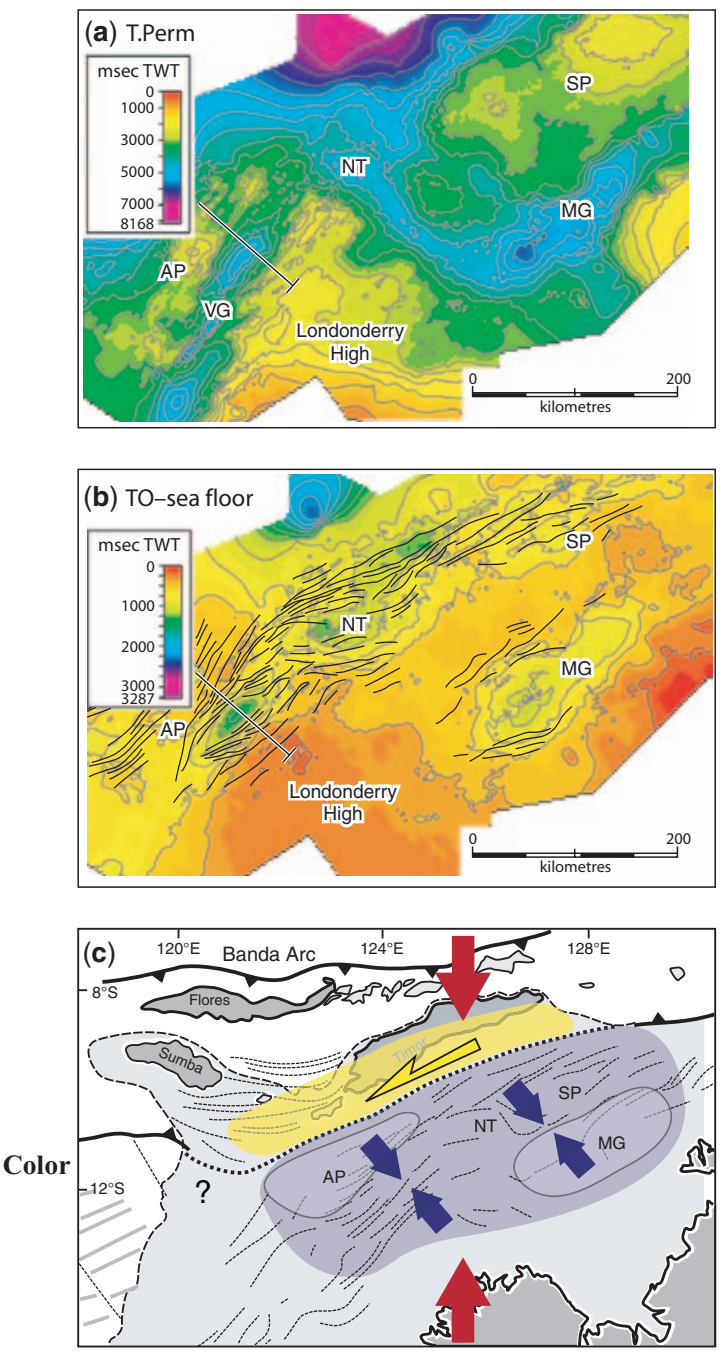

Fig. 13. Neogene deformation of the Bonaparte upper-plate compartment after Harrowfield et al. (2003); abbreviations as per Figure 2. The structural relief of the (a) buried Permian rift is mimicked by (b) fault-bound thickness variations (TWT) in the Neogene-Recent isochore. Harrowfield et al. (2003) interpreted Neogene faulting to reflect flexure of cover about amplified basement topography; (c) Driven by a north-south remote compressive stress (red arrows), pure-shear flexure of the Bonaparte Basin (blue region and arrows) is inferred to reflect partitioned sinistral strike-slip (i.e. simple shear) deformation outboard of the Ashmore Platform (yellow region).

increased wavelength of Jurassic and syn-rift architecture (Fig. 7a); second, increased basement depth and thickness of Cretaceous-Recent cover (Etheridge \& O'Brien 1994; Blevin et al. 1998); and third, reduced Neogene strain accumulation at distance from the collisional margin. The first explanation is consistent with the transition to soft-linked lower-plate rift margin architecture at basement levels (Struckmeyer et al. 1998), i.e. syn-rift architecture itself was less controlled by discrete faults, more influenced by ductile relay ramps and thus more continuous over greater length scales than the hard-linked Bonaparte compartment. The second cause is characteristic of increased subsidence of lower plate compartments during post-rift thermal recovery or 'sag' (as per Lister et al. 1991) and resultant inter-compartment relief across the BrowseBonaparte Transition (Fig. 7a). The third reason is consistent with the apparent decline of Neogene structural relief and deformation intensity southward across the Browse-Bonaparte Transition.

Locally, similar rotations of Neogene structural grain are associated with intra-compartment relief and corresponding variations in cover thickness. At the northern end of the Vulcan Graben, lowamplitude Mesozoic architecture and thicker postJurassic cover coincide with structural rotations and east-west Neogene fault trends in the Nancar Trough and across the Laminaria High (Fig. 10) (Shuster et al. 1998; de Ruig et al. 2000). Conversely, in the southern Browse Basin, where post-rift cover thins over the Leveque Shelf, Neogene fault trends and isopach lineaments trend parallel to basement faults of the lower-plate margin (Fig. 10) (Keep et al. 2000). Thus the Neogene structural grain is observed to rotate towards greater obliquity with the convergence vector of the Indo-Australian plate (Fig. 1) and inferred driving stress of Neogene deformation with inferred relaxation of basement control.

Neogene modification of the Browse Basin was associated with subtle amplification of Jurassic and older structural relief, accommodated by both faulting and continuous deformation of pre-tectonic Aptian-Oligocene cover (Fig. 9). The MioceneRecent depocentre was constrained by the Scott Reef Trend, the Browse-Bonaparte Transition and the palaeobathymetry of the Oxfordian depocentre. Thus modification of both the Browse and Bonaparte basins was associated with (1) the subtle amplification of basement structural relief and (2) a continuum of normal faulting. We therefore interpret Neogene deformation of the Browse Basin to be continuous with contractional flexure of the adjacent Bonaparte Basin (Fig. 12) (Harrowfield et al. 2003).

In both basins, Oxfordian structural relief was itself a low-amplitude replica of Jurassic architecture (Figs 3 \& 9) (Chen et al. 2002). Thus both Neogene and Oxfordian structural relief mimicked the architecture of syn-rift basement. These two phases of modification, associated with virtually 
identical patterns of sedimentary infill (Fig. 7a \& f), heightened relief between the Browse and Bonaparte compartments, and both phases resulted in amplification and erosion of outboard highs, subsidence of inboard troughs (O'Brien et al. 1993) and a decline in architectural relief southward across the Browse-Bonaparte Transition. Neither comparment shows evidence of any significant shortening or lengthing normal to strike (Chen et al. 2002). Whereas Neogene deformation reflects platemargin collision, Jurassic modification was spatially and temporally associated with seafloor spreading at the continent-ocean boundary (Muller et al. 1998). Similar correlations between seafloor spreading and weak contractional modification of passive margins have been described from SE Australia (Holdgate et al. 2003), the North American passive margin (Withjack et al. 1998), the North Atlantic Margin (Doré et al. 1999) and, locally, the diachronously equivalent Cretaceous interval within the Carnarvon Basin (Baillie \& Jacobson 1995). However, in the Browse Basin there was one substantial difference between Jurassic and Neogene architecture: whereas Jurassic faults paralleled syn-rift structure (Fig. 2) (Struckmeyer et al. 1998), Neogene faults were obliquely oriented (Fig. 10).

Basement and cover fault trends are continuous across and oblique to the architectural relief of the Browse-Bonaparte Transition (Figs $2 \& 10$ ). The Browse-Bonaparte Transition is thus more akin to soft-linked rupture-barrier style accommodation zones (i.e. a continuous basement ridge; e.g. Faulds \& Geissman 1992) than to transfer style (i.e. fault bound) accommodation zones (e.g. Coffield \& Schamel 1989; Hayward \& Ebinger 1996). A rupture-barrier style origin, thought to reflect compartmentalization of syn-rift extension (Faulds \& Geissman 1992), is consistent with both continuous Neogene amplification of the BrowseBonaparte Transition and the inferred change in fault linkage mechanism (i.e. uncoupling of the two fault populations) between the Browse and Bonaparte basins. The linear geophysical expression of the Browse-Bonaparte Transition, uncharacteristic of accommodation zones in modern rift settings (e.g. Upcott et al. 1996) and apparently unrelated to syn-rift faulting (Fig. 2), possibly reflects inheritance of the older Devonian-Carboniferous structural grain of the Petrel Basin (Fig. 2).

The Browse-Bonaparte Transition compartmentalized infill of both Jurassic and Neogene structural relief. Jurassic flexure, presumed to have been driven by orthogonal seafloor spreading, was coaxial with and hard-linked to syn-rift (Mesozoic) architecture. Neogene flexure, driven by oblique collision, varied complexly between hard-linked/coaxial deformation and soft-linked/ oblique deformation because of variations in basement structural relief and cover thickness. Regardless, both episodes caused amplification of long-wavelength relief between the Browse and Bonaparte Basins. Thus, weak flexural deformation, driven by both rifting and early-stage orogenesis, is interpreted to have actively contributed to longlived compartmentalization of the North West Shelf (Fig. 12).

\section{Conclusions}

We conclude that Neogene modification of the Timor Sea region reflects contractional deformation of a collisional plate margin; in effect, early-stage orogenesis. Our model has several interesting ramifications.

1. Any elastic amplification at basement levels (in accordance with Etheridge et al. 1991) might have been recoverable following accretion of the Banda Arc. This may explain why Ashmore Reef, a structural high and erosional locus during the Plio-Pleistocene, is now stranded below the apex of shelf topography.

2. Neogene deformation and depocentre growth did not result from penetrative strike-slip modification of the North West Shelf. Neogene depocentres represent troughs of apparent subsidence contained by zones of diffuse uplift.

3. Neogene-Recent tectonism amplified basement topography over wavelengths of several hundred kilometres. This vertical exaggeration was associated with negligible horizontal length change (i.e. very small distributed strain).

4. Shallow Neogene faulting accommodated thin-skinned gravitational collapse of detached sedimentary cover. At depth, Neogene deformation was manifested as continuous flexural shortening. This shortening was oblique to the trajectory of the Australian continent and the inferred tectonic stress.

5. The transcurrent component of Neogene deformation was partitioned outboard of any continuous flexural amplification. We speculate that left-lateral shear was partitioned adjacent to the present-day Timor Trough.

\section{References}

Australian Geological Survey Organisation (AGSO) North West Shelf Study Group. 1994. Deep reflections on the North West Shelf: changing perspectives of basin formation. In: PURCELL, P. G. \& $\mathbf{Q 2}$ Purcell, R. R. (eds) The Sedimentary Basins of Western Australia. Proceedings of the Petroleum Exploration Society of Australia, Perth, 63-74. 
Baillie, P. W. \& JACobson, E. 1995. Structural evolution of the Carnarvon Terrace, Western Australia. Australian Petroleum Production and Exploration Journal, 35, 321-331.

Blevin, J. E., Struckmeyer, H. I. M., Cathro, D. L., ET AL. 1998. Tectonostratigraphic framework and petroleum systems of the Browse Basin, North West Shelf. In: Purcell, P. G. \& Purcell, R. R. (eds) The Sedimentary Basins of Western Australia, 2. Proceedings of the Petroleum Exploration Society of Australia, Perth, 369-420.

Chen, G., Hill, K. C., Hoffman, N. \& O’Brien, G. W. 2002. Geodynamic evolution of the Vulcan sub-basin, Timor Sea, northwest Australia: a pre-compression New Guinea Analogue? Australian Journal of Earth Sciences, 49, 719-736.

Coffield, D. Q. \& Schamel, S. 1989. Surface expression of accommodation zone within the Gulf of Suez rift, Egypt. Geology, 17, 76-79.

De Ruig, M. J., Trupp, M., Bishop, D. J., KueK, D. \& CAstillo, D. A. 2000. Fault Architecture in the Nancar Trough/Laminaria Area of the Timor Sea, Northern Australia. Australian Petroleum Production and Exploration Journal, 40, 174-193.

Doré, A. G., Lundin, E. R., Jensen, L. N., Birkeland, O., Eliassen, P. E. \& Fichler, C. 1999. Principal tectonic events in the evolution of the Northwest European Atlantic margin. In: FLEET, A. J. \& Boldy, S. A. R. (eds) Petroleum Geology of Northwest Europe: Proceedings of the 5th Petroleum Geology Conference. Geological Society, London, 41-61.

Duddy, I. R., Green, P. F., Gibson, H. J. \& Hegarty, K. A. 2004. Regional Palaeothermal episodes in Northern Australia. Timor Sea Petroleum Geoscience. Proceedings of the Timor Sea Symposium. Petroleum Exploration Society of Australia, 567-591.

Elliot, C. I. 1994. Lineament Tectonics; an approach to basin analysis and exploration. In: PURCELL, P. G. \& Purcell, R. R. (eds) The Sedimentary Basins of Western Australia. Proceedings of the Petroleum Exploration Society of Australia, Perth, 77-90.

Etheridge, M. A. \& O’Brien, G. W. 1994. Structural and tectonic evolution of the Western Australian margin basin system. Petroleum Exploration Society of Australia Journal, 22, 45-64.

Etheridge, M., MCQueEn, H. \& LAmbeck, K. 1991. The role of intraplate stress in Tertiary (and Mesozoic) deformation of the Australian Continent and its margins: a key factor in petroleum trap formation. Exploration Geophysics, 22, 123-128.

FAulDS, J. E. \& GEISSMAN, J. W. 1992. Implications of palaeomagnetic data on Miocene extension near a major accommodation zone in the Basin and Range Province, northwestern Arizona and southern Nevada. Tectonics, 11, 204-227.

Harrowfield, M., Cunneen, J., Keep, M. \& Crowe, W. 2003. Early-stage orogenesis in the Timor Sea Region, NW Australia. Journal of the Geological Society, London, 160, 991-1002.

HAYWARD, N. J. \& EBINGER, C. J. 1996. Variations in the along-axis segmentation of the Afar rift system. Tectonics, 15, 244-257.
Hillis, R. 1992. Evidence for Pliocene erosion at Ashmore Reef (Timor Sea) from the sonic velocities of Neogene limestone formations. Exploration Geophysics, 23, 489-495.

Holdgate, G. R., Rodriquez, C., Johnstone, E. M., Wallace, M. W. \& Gallagher, S. J. 2003. The Gippsland Basin Top Latrobe unconformity and its expression in other southeast Australian Basins. Australian Petroleum Production and Exploration Association Journal, 43, 149-173.

Keep, M., Bishop, A. \& Longley, I. 2000. Neogene wrench reactivation of the Barcoo sub-basin, northwest Australia: implications for Neogene tectonics of the Australian margin. Petroleum Geoscience, 6, $211-220$.

Keep, M., Clough, M. \& Langhi, L. 2002. Neogene tectonic and structural evolution of the Timor Sea, NW Australia. In: KeEP, M. \& Moss, S. (eds) The Sedimentary Basins of Western Australia 3. Proceedings of the Petroleum Exploration Society of Australia, Perth, 341-355.

Lister, G. S., Etheridge, M. A. \& Symonds, P. A. 1991. Detachment models for the formation of passive margins. Tectonics, 10, 1038-1064.

Longley, I. M., Buessenschuett, C., Clydsdale, L., ET AL. 2002. The North West Shelf of Australia: a Woodside perspective. In: KEEP, M. \& Moss, S. (eds) The Sedimentary Basins of Western Australia 3. Proceedings of the Petroleum Exploration Society of Australia, Perth, 27-88.

Muller, R. D., Mihut, D. \& Baldwin, S. 1998. A new kinematic model for the formation and evolution of the west and -northwest Australian Margin. In: Purcell, P. G. \& Purcell, R. R. (eds) The Sedi- Q2 mentary Basins of Western Australia 2. Proceedings of the Petroleum Exploration Society of Australia, Perth, 55-72.

NELSON, A. 1993. Wrench and inversion structures in the Timor Sea region. Petroleum Exploration Society of Australia Journal, 29, 3-30.

O’Brien, G. W., Etheridge, M. A., Willcox, J. B., Morse, M., Symonds, P., Norman, C. \& NeEdHAM, D. J. 1993. The structural architecture of the Timor Sea, North Western Australia: implications for basin development and hydrocarbon exploration. Petroleum Exploration Society of Australia Journal, 33, 258-275.

O’Brien, G. W., Morse, M., Wilson, D., Quaife, P., Colwell, J., Higgins, R. \& Foster, C. B. 1999. Margin-scale, basement-involved compartmentalisation of Australia's North West Shelf: a primary control on basin-scale rift, depositional and reactivation histories. Australian Petroleum Production and Exploration Association Journal, 39, 40-61.

Pattillo, J. \& Nicholls, P. J. 1990. A tectonostratigraphic framework for the Vulcan Graben, Timor Sea Region. Australian Petroleum Exploration Association Journal, 30, 27-51.

Shuster, M. W., Eaton, S., Wakefield, L. L. \& Kloosterman, H. J. 1998. Neogene tectonics, greater Timor Sea, offshore Australia: implications for trap risk. Australian Petroleum Production and Exploration Association Journal, 38, 351-378. 
Struckmeyer, H. I. M., Blevin, J. E., SAyers, J., Totterdell, J. M., BAXter, K. \& CAthro, D. 1998. Structural evolution of the Browse Basin, North West Shelf: new concepts from-deep-seismic data. In: Purcell, P. G. \& Purcell, R. R. (eds) The Sedimentary Basins of Western Australia 2. Proceedings of the Petroleum Exploration Society of Australia, Perth, 345-367.

Upcott, N. M., Mikas A, R. K. \& Ebinger, C. J. 1996. Along-axis segmentation and isostacy in the Western Rift, east Africa. Journal of Geophysical Research, 101, 3247-3268.

Walsh, J. J. \& WATterson, J. 1987. Distributions of cumulative displacement and seismic slip on a single normal fault. Journal of Structural Geology, 9, 1039-1046.
Withjack, M. O., Schlische, R. W. \& Olsen, P. E. 1998. Diachronous rifting, drifting, and inversion on the passive margin of Central Eastern North America: an analogue for other passive margins. American Association of Petroleum Geologists Journal, 82, 817-835. Q3

Woods, E. P. 1988. Extensional Structures of the Jabiru Terrace, Vulcan sub-basin. In: PURCELL, P. G. \& Q2 PurCELl, R. R. (eds) The North West Shelf, Australia. Proceedings of the Petroleum Exploration Society of Australia, Perth, 311-330.

Yeates, A. N., Bradshaw, M. T., Dickins, J. M., ET AL. 1987. The Westralian Superbasin, as Australian link with Tethys. In: MckenzIE, K. G. (ed.) Shallow Tethys 2. 2nd International symposium on Shallow Tethys A.A. Balkema, Rotterdam, 199-213. 